\title{
Symptoms and Treatment of Low Blood Glucose ${ }^{1}$
}

\author{
Linda B. Bobroff ${ }^{2}$
}

Low blood glucose, also called hypoglycemia, can be life-threatening for people with diabetes. It can be caused by eating too little food, taking too much insulin or other diabetes medication, or being extra active. If left untreated, low blood glucose can progress to diabetic coma. Everyone with diabetes needs to know the symptoms of low blood glucose so they can take action right away.* If you work or live with someone who has diabetes, you should know the symptoms and treatment, too!

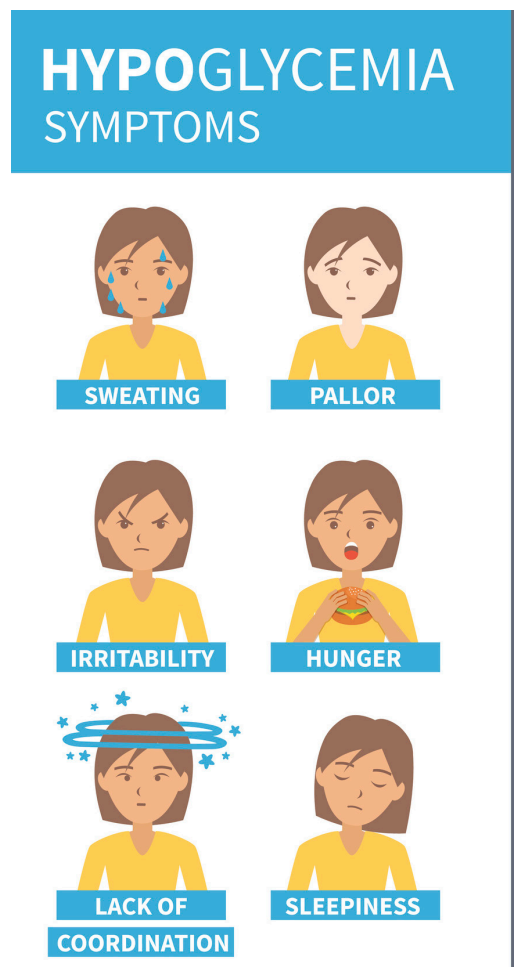

Figure 1. Symptoms of hypoglycemia can range from mild to severe. Credits: Irina_Strelnikova / iStock / Getty Images Plus
${ }^{*}$ The only way to know for sure that your blood glucose is low is to test it with your meter. If you are using a continuous glucose monitoring system, it is still recommended that you test your blood glucose with your meter if you are having symptoms.

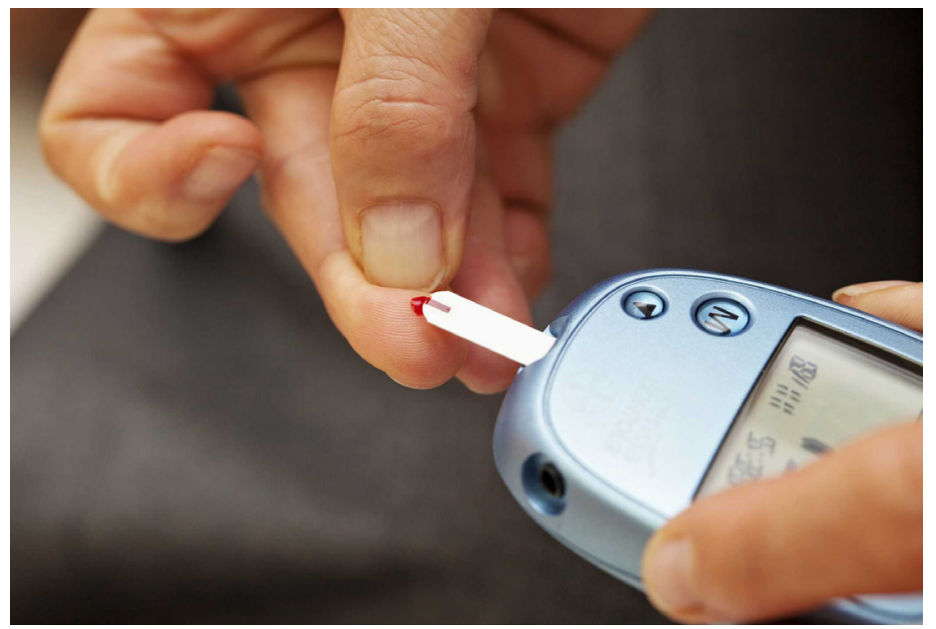

Figure 2. The only way to know if your blood glucose is low is to test. Credits: vitapix / iStock / Getty Images Plus

\section{Treating Low Blood Glucose} Be prepared before you feel symptoms!

- Ask your doctor what "number" is low blood glucose for you. That way you will know ahead of time when to treat yourself. Also, ask how much sugar to take if your blood glucose is low.

- Always carry pre-measured sugar. The most convenient forms are glucose tablets or gel, table sugar, or hard

1. This document is FCS8749, one of a series of the Department of Family, Youth and Community Sciences, UF/IFAS Extension. Original publication date August 2002. Revised February 2018. Visit the EDIS website at http://edis.ifas.ufl.edu.

2. Linda B. Bobroff, PhD, RDN, professor, Department of Family, Youth and Community Sciences; UF/IFAS Extension, Gainesville, FL 32611.

The Institute of Food and Agricultural Sciences (IFAS) is an Equal Opportunity Institution authorized to provide research, educational information and other services only to individuals and institutions that function with non-discrimination with respect to race, creed, color, religion, age, disability, sex, sexual orientation, marital status, national origin, political opinions or affiliations. For more information on obtaining other UF/IFAS Extension publications, contact your county's UF/IFAS Extension office. 
candy. The appropriate amount needed to treat low blood glucose is 15 to 20 grams.

- Many people confuse symptoms of low blood sugar with general fatigue or weakness, so it is important to TEST. If you are not able to test your blood glucose, it is okay to treat for low blood glucose because it can result in a medical emergency.

- If you are at high risk for very low blood glucose (below $54 \mathrm{mg} / \mathrm{dL}$ ), you should also have a glucagon kit available at all times. Anyone you spend considerable time with, such as family members, teachers, or caregivers, should know how to administer glucagon in case of an emergency.

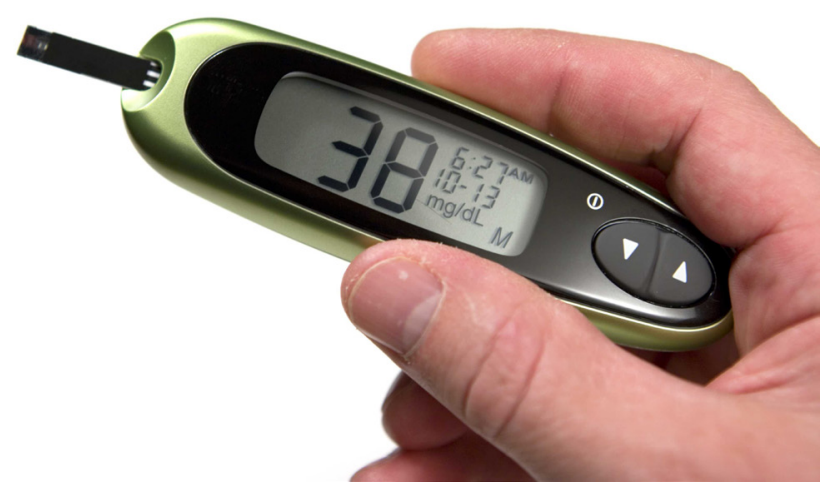

Figure 3. Blood glucose below $54 \mathrm{mg} / \mathrm{dL}$ is severe hypoglycemia that can lead to seizures or unconsciousness.

Credits: MarkHatfield / gettyimages.com

\section{When You Feel Symptoms}

STEP 1. Check your blood glucose. If you cannot check your blood, but feel like your blood glucose is low, treat it as low.

STEP 2. If your blood glucose is low (or you feel that it is low), eat something that will get glucose into your blood quickly.

If your blood glucose is less than $70 \mathrm{mg} / \mathrm{dL}^{*}$ :

- Eat 15-20 grams of sugar (see list of foods).

- Wait 15 minutes and test again.

- If still below $70 \mathrm{mg} / \mathrm{dL}$, eat 15-20 grams of sugar again.

- Repeat until your blood glucose returns to normal.

- If your blood glucose does not return to normal after treating with glucose as described, call your doctor or 911, or have someone drive you to the emergency room. Do NOT drive when your blood glucose is low.

Severe hypoglycemia leading to unconsciousness or a seizure is a medical emergency. If your blood glucose is less than $54 \mathrm{mg} / \mathrm{dL}$ and you are not capable of treating yourself with sugar, then it is necessary for someone to administer glucagon via injection. If you do not respond to glucagon by regaining consciousness within about 15 minutes, then 911 should be called. Even if you do respond to glucagon treatment, it is a good idea to be seen by a physician as soon as possible, either in an office or the emergency room.

Table 1. Foods with 10 to 15 grams of sugar.

\begin{tabular}{|l|l|}
\hline 1 tablespoon sugar & $\begin{array}{l}5 \text { to } 7 \text { Lifesavers }^{\circledR} \text { (check } \\
\text { Nutrition Facts) }\end{array}$ \\
\hline 1 tablespoon honey & $\begin{array}{l}6 \text { jellybeans (check Nutrition } \\
\text { Facts) }\end{array}$ \\
\hline 1 tablespoon corn syrup & $\begin{array}{l}10 \text { gumdrops (check Nutrition } \\
\text { Facts) }\end{array}$ \\
\hline 2 tablespoons raisins & 1 cup fat-free or $1 \%$ milk \\
\hline $1 / 2$ cup regular soda (NOT diet) & $\begin{array}{l}\text { glucose tablets (typically } 4) \\
\text { or gel tube (follow package } \\
\text { instructions) }\end{array}$ \\
\hline $1 / 2$ cup fruit juice & \\
\hline
\end{tabular}

\section{After Treating Low Blood Glucose}

If you will not be eating a meal within 30 minutes, have a snack with protein and carbohydrate. Snack ideas include:

- Peanut butter and crackers or cheese and crackers

- Half of a sandwich (cheese, meat, or peanut butter)

Discuss a plan ahead of time with your medical team regarding the way to handle your insulin or diabetes medication regimen after treating a low blood glucose event.

${ }^{\star} \mathrm{mg} / \mathrm{dL}=$ milligrams per deciliter of blood

\section{References}

American Diabetes Association. (n.d.). Hypoglycemia (low blood glucose). Accessed on February 22, 2018. http:// www.diabetes.org/living-with-diabetes/treatment-and-care/ blood-glucose-control/hypoglycemia-low-blood.html

American Diabetes Association. (2017). 6. Glycemic targets. Diabetes Care, 40(suppl. 1), S48-S56. http://care. diabetesjournals.org/content/40/Supplement_1/S48

Kedia, N. (2011). Treatment of severe diabetic hypoglycemia with glucagon: an underutilized therapeutic approach. Diabetes Metabolic Syndrome and Obesity: Targets and Therapy, 4, 337-346. 